\title{
THE SKILL BIAS EFFECT OF TECHNOLOGICAL AND ORGANISATIONAL CHANGE: EVIDENCE AND POLICY IMPLICATIONS ${ }^{\circ}$
}

\author{
Mariacristina Piva*, Enrico Santarelli** and Marco Vivarelli***
}

\begin{abstract}
Previous empirical literature has shown that technological change can be considered the main cause of the skill bias (increase in the number of high skilled workers) exhibited by manufacturing employment in developed countries over the last decades. However, recent papers have also introduced the "Skill Biased Organisational Change" hypothesis. We estimate a SUR model for a sample of 400 Italian manufacturing firms, showing that the upskilling is more a function of the reorganisational strategy than a consequence of technological change alone. Moreover, some evidence of superadditive effects emerges, consistently with the theoretical hypothesis of a coevolution of technology and organisation.
\end{abstract}

\section{JEL classification: $\mathbf{O 3 3}$}

Keywords: Skill Bias; Organisational Change; Manufacturing.

\section{October 2003}

* Catholic University, Department of Economic and Social Sciences, Piacenza.

** University of Bologna, Department of Economics and Free University of Bozen/Bolzano, School of Economics and Management.

*** Catholic University, Department of Economic and Social Sciences, Piacenza; International Labour Office (ILO, Geneva) and Institute for the Study of Labour (IZA, Bonn).

Corresponding author: Marco Vivarelli, Catholic University, Department of Economic and Social Sciences, Via Emilia Parmense 84, I-29100 Piacenza, Italy.

Phone: +39 0523599 301; Fax: +39 0523599 303; E-mail: marco.vivarelli@unicatt.it.

\footnotetext{
This paper is part of the research project Patterns and determinants of skill biased technical change in a mediumtechnology country. Financial support from MIUR (Year 2001; protocol \#133591_002; project leader: E. Santarelli) is gratefully acknowledged. A previous version was presented at the "Ninth Workshop on Alternative Economic Policy in Europe" (Free University of Brussels, 26-28 September, 2003).
} 


\section{Introduction}

The long-term empirical evidence for many countries shows that the number of skilled workers (in particular graduates) has grown over time. Vis-à-vis this process of "knowledge deepening" occurring in most production activities, a marked and widening wage inequality has been observed between more skilled and less skilled workers. This second item of evidence is in contrast with both the simple supply and demand view, according to which an increase in the number of skilled workers should result in less wage inequality, and the historical evidence dating back to the First Industrial Revolution, when low skilled labour and machines replaced skilled artisans. A possible explanation for this process is that, as the returns to education rise due to technology, more people respond to these pay incentives by acquiring tertiary qualifications, with a consequent increase in the supply of skilled workers. Nevertheless, there is also room for at least three other possible theoretical explanations, respectively identifying the main determinants of the observed shift from unskilled to skilled labour in technology alone, in reorganisation processes occurring within the firm, and in a combination of these two aspects.

In this connection, over the past two decades the economic literature (see next section) has offered an explanation of this empirical evidence based on the so-called "Skill Biased Technological Change" (SBTC) hypothesis, according to which the reason for the upskilling of the labour force is the non-neutrality of technological change, which benefits skilled labour more than other production factors. Because technology is complementary to skills, acceleration in the rate of technological change increases the demand for skilled labour; yet it is also true that an increase in the supply of skills induces faster technological change (see, among others, Greiner et al., 2001). 
One explanation put forward by economists to reconcile these facts hinges on the nature of technological change over the past two decades. Indeed, whilst the phenomenon of SBTC appears to be a long-term historical trend (see Nelson and Winter, 1982; Dosi, 1988; Goldin and Katz, 1998, Von Tunzelmann and Anderson, 1998), the diffusion of Information and Communication Technology (ICT) seems to have given new impetus to the substitution of unskilled workers with skilled ones. As technologies like ICT proved successful in raising the marginal productivity of skilled labour relative to unskilled labour, they also made it relatively more economical to employ skilled workers in place of unskilled ones. Accordingly, Michel and Bernstein (1966) and Wood (1995) argue that the 1980s witnessed an acceleration in SBTC which resulted in rising skill premia ${ }^{1}$ in many countries (see also Aghion and Howitt, 2002). However, since the evidence for this acceleration is mixed (see Autor et al., 1998), one might contend that, within a multi-sector framework, it is mostly the sector bias of technological change that is in operation, rather than the factor bias usually mentioned by labour economists. This explanation is consistent with empirical evidence supporting the SBTC hypothesis for high-tech countries (such as the US and the UK) but not for medium or low-tech ones (including other European countries, see Section 2.1).

Given that the literature is inconclusive on whether technological change favours a certain factor of production, or is more likely to occur in certain sectors than in others (see Haskel and Slaughter, 2002), some researchers looked for other possible complementary explanations of the skill bias. Among trade economists, these alternatives are connected to globalisation ${ }^{2}$, whereas

\footnotetext{
${ }^{1}$ Defined as the ratio between the wages earned by high-skilled workers and the wages earned by low-skilled workers.

${ }^{2}$ This strand of literature supports the hypothesis that increased volumes of world trade and FDI cause a reallocation of the labour force, shifting activities involving unskilled workers towards the least developed countries, while activities involving the production of skill-intensive goods remain in developed countries (Wood, 1994; for an empirical test on Italian data see Manasse et al., 2003). Owing to a lack of data, testing this hypothesis empirically is
} 
among industrial and managerial economists they concern the reorganisation of production. In this paper, which adopts the approach put forward by industrial and managerial economists, attention will focus on the role of organisational change and the possibility that technology and reorganization exert a joint superadditive effect in influencing the demand for skills. The paper is organized as follows. Section 2 reports some evidence on the general upskilling trend in manufacturing across developed countries and discusses the economic literature on the role of technological and organisational changes as a possible explanation for the skill bias. Section 3 sets out our empirical analysis based on a sample of 400 Italian manufacturing firms, while policy implications are discussed in Section 4. Finally, some conclusive considerations are presented in Section 5.

\section{Comparative evidence and survey of the literature}

The OECD Secretariat collected comparative data on employment broken down by occupation (high and low-skilled white-collars and high and low-skilled blue-collars) for a few OECD countries during the 1980s and the beginning of the 1990s (OECD, 1996 and 1998). Unfortunately, this database has not been updated for the years following 1993. We have reconstructed more recent figures ${ }^{3}$ relative to the manufacturing sector alone for the G-7 countries, maintaining a dichotomic division between skilled workers (white-collars, WC) and unskilled ones (blue-collars, BC).

often a difficult undertaking; however, some studies on the subject have not found a strong support for this explanation of the skill bias (see Slaughter; 2000; Piva and Vivarelli, 2002 and 2004). This hypothesis will not be discussed and tested in the present paper.

${ }^{3}$ Data are not comparable between countries due to different sources and various classifications of occupations (see the note to Figure 1); however, they provide important information on the dynamics of the demand for skilled workers within each country. 
These data can be used to examine the changing skill composition. Figure 1 depicts the change in the structure of manufacturing employment in the G-7 countries over the 1990s. At first glance, there is a persistent upskilling trend of the workforce in all countries: the relative share of WC is increasing everywhere, even in the most recent years (see Piva and Vivarelli, 2002, for consistent previous results based on OECD data over the ' 80 s).

Nevertheless, over the past few decades, the demand for skilled workers seems to have grown more rapidly than the corresponding labour supply, since skilled workers are not only more easily employed but, under certain circumstances, they are also proportionally much better paid than the unskilled (see Nickell and Bell, 1995; Haskel and Slaughter, 2002).

Consistently with the different national institutional contexts, skill bias has caused increasing unemployment of unskilled workers in continental European countries (Machin and Van Reenen, 1998) and has had stronger effects on the wage dispersion between the skilled and unskilled in the US and - to a lesser extent - the UK (Krueger, 1993; Autor et al., 1998).

Concern over the worsening social economic position of the unskilled has induced researchers to seek better understanding of the skill bias effect. Recent theoretical and empirical research can be surveyed by starting with the early studies, which only dealt with technological change, and then analysing the recent strand of literature which examines the role of organisational change, either alone or in interaction with technology.

$<$ INSERT FIGURE $1>$

\subsection{Technology alone: the SBTC hypothesis}

The SBTC hypothesis is based on the idea that there is a strong complementarity between new technologies and skilled workers, given that only the latter are able fully to implement those 
technologies ${ }^{4}$. Empirical studies testing this hypothesis, either at the firm or the industry level, have been carried out with regard to the manufacturing sectors of various developed countries. Most of these studies focus on the factor bias of SBTC.

As far as the US is concerned, there is substantial and consistent evidence supporting the SBTC hypothesis. Among the most recent and most representative papers, Berman et al. (1994) at the sectoral level - and Dunne et al. (1996) - at the firm level - have found a positive and significant relationship between R\&D and skilled labour in the US. Doms et al. (1997) - for firms in some US manufacturing sectors - have shown that the use of the most advanced industrial technologies leads to the greater utilisation of workers with higher qualifications. Another test of the SBTC hypothesis was conducted by Siegel (1998), who found evidence of upskilling in those Long Island manufacturing plants that had introduced new technologies. With regard to a particular sector - US chemical firms - Adams (1999) showed the skill bias nature of R\&D expenditure and innovative investments.

In Canada, both Betts (1997), who examined manufacturing, and Gera, Gu and Lin (1999), who focused on both the manufacturing and service sectors (1981-94), showed a connection between several different measures of technology and the growing demand for skilled workers.

For the UK, Machin (1996) - using both sector-level and firm-level data in the 1990s and Haskel and Heden (1999) - at the firm level - demonstrated respectively a positive relation between R\&D intensity, number of innovations produced and used, and skilled labour (in the sector analysis), and both studies found a correlation between the use of computers and skilled labour in the case of firms.

\footnotetext{
${ }^{4}$ For a theoretical survey, see Pianta (2003).
} 
The results of studies dealing with other countries have generally confirmed the SBTC hypothesis, although less robustly than in the case of the British and North American economies.

In France, Mairesse et al. (2001) obtained results similar to those of Machin (1996) for firm level data where the technological variables were ICT capital and ICT workers. However, only the negative relation between ICT and less-qualified labour was robust in the time-series estimations. This confirmed the results of Goux and Maurin (2000), who showed that an increased spread of new technology accounted for only $15 \%$ of the change in labour demand between 1970 and 1993.

For Spain, Aguirregabiria and Alonso-Borrego (2001) used a panel of 1080 firms and tested the relation between new technologies and upskilling, using the GMM estimator for dynamic panels. With a dummy on the introduction of "technological capital" used as the technological variable, the SBTC hypothesis was confirmed, while no significant effect emerged with respect to $R \& D$ expenditure.

In Germany, Falk (1999) showed that the joint implementation of new products and processes had the greatest effect on the employment structure, exerting the strongest positive impact on the demand for university graduates. This result was also confirmed by Falk and Koebel (2003). Their empirical analysis indicated that the accumulation of office machinery and computer capital stock - in 35 German industries over the period 1978-94 - was a relevant factor contributing to the shift in labour demand towards highly skilled workers (university graduates).

Machin and Van Reenen (1998) studied the phenomenon beyond the national level. They set up a panel (at the manufacturing-sector level for 7 developed countries over the period 197389) and showed that the relative demand for skilled workers was positively linked to R\&D expenditure. 


\subsection{Organisation alone: the SBOC hypothesis}

This second strand of literature is based on the hypothesis that the increasing diffusion of reorganisation processes within firms plays a role in the increasing demand for skilled workers.

In general terms, organisational change is becoming increasingly important, and the empirical literature on the subject is growing rapidly in significance. The basic idea is that a progressive shift from rigid, Tayloristic, segmented organisations towards more flexible and "holistic" ones is taking place within firms (see Lindbeck and Snower, 1996). This phenomenon first appeared in the US and Japan and has since spread throughout Europe, although with different intensities from country to country (see Aoki, 1986; Greenan and Guellec, 1994; OECD, 1999). It is impossible here to give thorough treatment of the vast literature - whose basic intuitions can be traced back to Chandler, 1962 - on organisational change and its impact on firm's structure and performance. Suffice it to point out that economic, management and sociological studies on the subject seem to agree on the following recent trends (see, among others, Caroli, 2001, Colombo and Delmastro, 2002):

1) Decentralization and delayering: "lean production" is associated with new firm's functions such as just-in-time, management of breakdowns and quality controls, which in turn imply both the decentralisation of decision making and more involvement, responsibility and autonomy at the shopfloor level (see Brynjolfsson and Mendelson, 1993; Greenan, 1996a; Bresnahan, 1999).

2) Collective work: new work practices such as work teams and quality circles require collective efforts from the workforce (see Osterman, 1994). 
3) Multi-tasks: workers are now required both to perform a greater variety of tasks within a given occupation and to rotate among different jobs (see Greenan and Mairesse, 1999; Ichniowski and Shaw, 2003).

Moreover, the empirical literature reports that the organisational changes listed above generally occur at the same time, assuming the form of "clusters" of organisational innovations. For instance, Ichniowski et al. (1997), showed the complementarity of the introduction of teamwork, flexible job assignment and intensive workers-management communication in US steel manufacturing.

Obviously, organisational innovations such as those briefly described imply that the manufacturing workforce must be upskilled. Accordingly, the "skill biased organisational change" (SBOC) hypothesis has been put forward and tested ${ }^{5}$. For instance, Greenan and Guellec (1998), using a 1987 French survey on work organisation, found that organisational changes such as greater workers' autonomy and increased communication among workers - were positively correlated with skill upgrading ${ }^{6}$. Again with regard to France, Thesmar and Thoenig (2000) and Caroli et al. (2001), using large databases of French manufacturing firms, found respectively a strong negative correlation between product turnover - taken as a measure of organisational "creative destruction" - and blue-collar workers, and a skill bias effect of organisational change in association with a reduction in the firm's size, which probably suggests an evolution towards more flexible firms. Finally, Caroli and Van Reenen (2001), comparing two panels of French and British firms, focused mainly on organisational change (measured with a dummy). The results, which supported the SBOC hypothesis, turned out to be econometrically significant in both the panels. Finally, Greenan (2003), using a survey on organisational change 
in French manufacturing in 1993, found the increase in skill requirements is more closely connected to organisational than to technological change.

\subsection{Technological change associated with organisational change}

While Aghion et al. (1999) maintained that technological progress was the main cause of change, and that organisation was ancillary, a recent strand of the literature has tended to emphasize that technological change and organisational change are complementary to each other, and that they often generate superadditive effects in terms of firm's performance, measured either in terms of productivity or profitability (see Pavitt et al., 1989; Milgrom and Roberts, 1990 and 1995; Black and Lynch, $2001^{7}$ ).

Indeed, new ICT technologies modify the way in which decisions are made in a firm, often making hierarchies redundant because orders are replaced by interactions among workers (see Bolton and Dewatripont, 1994). ICTs, moreover, on the one hand facilitate lateral communication because they make delayering into a flatter organisation feasible, while on the other they increase the ability of shopfloor workers to perform information-intensive tasks (see Radner, 1993; Caroli, 2001).

In most countries, the introduction of ICTs does not appear to have generated any increase in productivity, probably because of the special nature of information technology. As pointed out by Gibson (2002) in his study on computers and the wage structure in New Zealand, ICT is mostly a "general purpose technology" (GPT), whose major impact on the economy is not direct

\footnotetext{
${ }^{5}$ To be noted is that the economic literature has been most concerned with the consequences of organisational change for productivity, while there have been few attempts to focus directly on skills.

${ }^{6}$ See also Greenan (1996b).
} 
but occurs through a wide range of secondary innovations. As a consequence, introduction of a new GPT does not immediately coincide with a surge in productivity growth; at least as long as firms invest in developing these secondary innovations. This experimentation phase requires both workers that are skilled and workers who are "adaptable", in the sense that they possess a combination of general knowledge and on-the-job experience that cannot be acquired through vocational and specific technical education but is learnt only from wide-ranging education and training.

The above theoretical considerations are supported by empirical evidence. For instance, on studying the impact of the implementation of advanced manufacturing technologies on Human Resource Management (HRM) practices, Siegel et al. (1997) found a strong correlation between these technologies and enhanced employee empowerment.

Brynjolfsson and Hitt (1998) demonstrated that ICT technologies and new work practices cluster together. More specifically, the stock of IT capital and number of PCs proved to be correlated with the diffusion of self-managing teams, workers' involvement in strategic decisions, and workers' discretion in planning their work.

Case studies at the level of individual firms are reviewed in Hitt and Brynjolfsson (2002), and they confirm the close complementarity between ICT diffusion and the three types of firm's reorganisation listed in Section 2.2 above.

Once it has been demonstrated that technological change and organisational change often go together, some studies have also shown - not surprisingly, given the results discussed in

\footnotetext{
7 Conversely, the mismatch between technological change and organizational inertia may generate an adverse impact on firm's performance (the so-called "Solow's paradox"; see Brynjolfsson et al., 1997; Brynjolfsson and Hitt, 2000).
} 
Sections 2.1 and 2.2 above - that this combined modification of firm's structure gives rise to an increase in the demand for skills.

For instance, Hitt and Brynjolfsson (1997) surveyed about four hundreds firms and found not only that greater levels of ICT were associated with increased delegation of authority to individuals and teams, but also that the combination of technological and organisational change involved a skill bias both in the firms' actual workforces and in their recruitment strategies.

More recently, Bresnahan et al. (2002), using data covering approximately 250 US firms (1987-94) in cross-section, have demonstrated that labour demand has undergone structural changes in favour of skilled workers only when the introduction of computers has been accompanied by reorganisation within the firm.

\section{Some results from Italian manufacturing}

In this section an empirical analysis of a sample of Italian manufacturing firms is presented, the purpose being to assess technological change and reorganisation as possible determinants of the skill bias in a medium-technology country.

The data are taken from a database of Italian manufacturing firms with no fewer than 11 employees. The database comprises the replies to three questionnaire waves administered by the investment bank Mediocredito Centrale (MCC) in 1991, 1994 and 1997, with each questionnaire collecting retrospective data for three years ${ }^{8}$. If only reliable and complete data strings overlapping the three waves were considered and obviouos outliers were excluded ${ }^{9}$, a sample of

\footnotetext{
8 To avoid the use of misleading data, firms subject to takeover or break-up involving major employment discontinuities were excluded from the sample. For the remaining cases, two dummy controls indicating whether the firm declared takeovers or break-ups were included.

${ }^{9}$ According to Grubbs' test.
} 
400 firms was obtained ${ }^{10}$. With reference to skills, the MCC data allowed identification of two broad categories of homogeneous workers: white-collars (WC, including the entrepreneur and family assistants, senior and junior managers, and office workers) and blue-collars (BC, manuals).

The econometric specification is conducted within a theoretical framework based on the transcendental logarithmic (or translog) firm cost function originally introduced by Kmenta (1967) to approximate the CES production function, and formally developed by Christensen et al. (1971 and 1973). The model used is in long differences (for a similar approach see Caroli and Van Reenen, 2001), so both eliminating firms' fixed effects and avoiding possible problems of endogeneity (see Acemoglu, 1998) ${ }^{11}$. For our purposes, the most appropriate approach for estimation is Zellner's (1962) seemingly unrelated regression (SUR), on the assumption that the right-hand part of the equation is independent of the error term, that the errors are crossed and that the method therefore guarantees greater efficiency compared with an OLS estimation of the single equations (for a similar econometric approach applied to the empirical analysis of the skill bias, see Machin et al., 1996; Betts, 1997; Adams, 1999). In this context, in our joint econometric specification the dependent variables are the log of differences (1991-97) in WC and BC. The aim is to test the role of the two possible determinants of the skill bias - measured as dummies which indicated the presence or absence of $\mathrm{R} \& \mathrm{D}$ expenditure and organisational changes $(\mathrm{ORG})^{12}$ in the previous period 1989-91- controlling for all contemporaneous determinants, such

\footnotetext{
${ }^{10}$ In 1997, the average firm's size in the sample is 350 employees (with a standard deviation of 609), the minimum firm's size is 12 and the maximum firm's size is 5000 .

${ }^{11}$ It was not possible to use a dynamic panel structure, because - in the MCC database - some determinants were not represented by variables with a temporal structure, but only by qualitative dummies (and in the case of the organisational dummy, information was only available for the first wave, i.e. for the first three-year period).

12 For R\&D the question in the questionnaire was "whether the firm has carried out investments in R\&D activity during the three years" and for ORG "whether the firm has carried out significant organisational changes in its
} 
as output (sales), capital and labour costs (WC and BC wages), which can influence the causative link that we want to study ${ }^{13}$.

Additional controls are included: three sector-fixed effects (sectors with high, medium and low technology $)^{14}$, five firm's size-fixed effects $(11-20 ; 21-50 ; 51-250 ; 251-500 ;>500$ employees), and two fixed effects related to takeovers or break-ups (TB) declared in the period 1991-97.

Table 1 gives the results. The first finding (columns 1 and 2) suggests that the alleged role of $\mathrm{R} \& \mathrm{D}$ alone in determining the skill bias is not robust to the econometric control, although exhibiting the expected signs ${ }^{15}$. As a matter of fact, Italian manufacturing comprises a large fringe of family business - some of which relatively large in size, as most of those in our sample (see footnote 10 above) - either operating in traditional industries or below the technological frontier when active in advanced sectors. These typical family firms are characterized by direct family involvement in daily operations, more than one family member with significant management responsibility, and multiple generations involved. They are therefore devoid of the features that are distinctive of Berle and Means (1932) corporations, including separation of ownership and control, presence of professional managers that exercise (nearly) full control, etc. (see Burkart et al., 2002). Hence, consistently with the findings of Haskel and Slaughter (2002),

structure". 192 firms out of 400 carried out investments in R\&D, 167 implemented significant organisational changes and 93 carried out both R\&D investments and organisational changes.

${ }^{13}$ Because the average annual wages of $\mathrm{WC}$ and BC workers were not provided by the MCC database, they were calculated by merging the MCC database with the INPS (Italian National Institute for Social Security) database. All the variables were deflated and expressed according to 1990 prices. Capital, K, was derived from the balance sheet item "net technical assets", while output, Y, was quantified in terms of sales.

${ }_{14}$ According to OECD (1998); this control resulted never significant and so has been dropped from the final estimates whose results are reported in Table 1.

${ }^{15}$ No significant effects of the technological variables can also be found in Aguirregabiria and Alonso-Borrego (2001) with regard to Spanish firms, in Greenan (2003) with regard to French firms and in Caroli and Van Reenen (2001) again with regard to French firms. Of course, this finding does not rule out a possible role for other forms of technological change such as knowledge embodied in new machinery and capital equipment and acquisition of 
in the case of our sample the shift from unskilled to skilled labour is unlikely to be driven uniquely by R\&D activities.

\section{$<$ INSERT TABLE $1>$}

The ORG variable is instead affecting the demands for $\mathrm{BC}$ and $\mathrm{WC}$ with the expected signs and turns out to be significant in determining redundancy of the unskilled. This is consistent with a view regarding Italy that can be traced back to Fuà (1988), who stressed the importance of the so-called organisational-entrepreneurial factor in re-shaping the profile of those Italian firms that are not relying on own $R \& D$ as the sole source of change.

Finally, in columns (5) and (6) an interaction dummy representing the joint presence of ORG and R\&D exhibits higher and more significant coefficients compared to ORG in previous estimates (3) and (4). This important result suggests a superadditive skill bias effect of reorganisation combined with technological change (see Section 2.3), and it is consistent with the findings summarized in Section 2.3 above. As a peculiarity of the Italian case, it should be noted that this joint effect seems to be unbalanced both in terms of statistical significance and values of the coefficients. In other words, organisational change combined with new technologies mainly implies redundancy of blue-collars and only weakly increases the demand for white-collars.

\section{Policy implications}

The descriptive statistics on the G-7 countries presented in Section 2 show a clear upskilling trend in manufacturing industries over the 1980s and 1990s. In the case of Italy, the analysis of a sample of manufacturing firms carried out in the present paper shows that the upskilling trend of employment appears to be mainly a function of the reorganisational strategy adopted by the 
firms, possibly combined with technological change. Moreover, workplace reorganisation appears to have weakly favoured more skilled (or qualified) workers, whereas blue-collars seem strongly vulnerable to the joint effect of reorganisation and implementation of new technologies.

In terms of policy prescriptions, these findings entail that reorganisational strategies should be coupled - at the level of the firm - with interventions on HRM, especially with regard to production workers. Indeed, the lack of complementary manpower strategies increases the likelihood of redundancy of blue-collar workers, particularly exposed to labour-saving organisational and technological changes (see Freeman and Soete, 1994). Hence, policy makers should support holistic strategies at the level of the firm (on-the-job training aimed at transferring non cognitive capabilities to workers), and they should promote education and off-the-job training. In other words, only education and training can maximise the joint impact of technological and organisational change on firms' performances and aggregate welfare ${ }^{16}$.

Some of the literature on technological change suggests that workers are better off with general rather than vocational education, because thus their skills are less likely to be rendered obsolete by technological progress. Similarly, qualitative evidence arising from discussions with entrepreneurs and firm insiders points to increasing demand not only for cognitive skills such as those captured by traditional measures of scholastic achievement, but also "sociability". These prescriptions are consistent with the empirical results discussed in the previous section: if skillupgrading is not triggered by technological change alone, but mainly by organisational change (possibly combined with the former), the need for engineers and IT technicians no longer emerges as paramount, while the increasing demand for multi-skilled and easily adaptable

\footnotetext{
Piergiovanni et al., 1997).

${ }^{16}$ Organisation, technology and skills are the three angles of the black triangle explaining economic performance in Caroli (2001).
} 
workforce calls for an increase in the supply of general education and training at the high and intermediate levels. The latter seems to be particularly important, since workers' involvement and their greater autonomy requires general knowledge even at the level of the workshop (bluecollars) and at that of routine clerical work ${ }^{17}$.

This policy implication appears to be consistent with the view of ICT as pervasive "general-purpose technologies" applicable across a wide range of functions and tasks (see Bresnahan and Trajtenberg, 1995; Freeman and Louçã, 2001). Moreover - and beyond the scope of this paper - it should also be borne in mind that ICT-based general purpose technologies also massively affect the services sector (see Kleinknecht, 2000), with the processes of SBTC and SBOC occurring in a similar manner to those detected in manufacturing activities and affecting both services workers and services consumers (see Petit and Soete, 2001) ${ }^{18}$. On this view, both technological change alone and the consequent organisational change require more general and adaptable skills rather than specific competences. Indeed, when new technologies and new organisational practices require the workforce to have task, functional and sectoral flexibility, and make specific skills rapidly obsolescent, secondary and tertiary education should be targeted more on general contents, models and methodologies rather than on specific technical competences. According to Bresnahan (1999) and Bresnahan et al. (2002), general education should also embrace a number of "noncognitive" skills, ranging from interpersonal skills to the ability to work steadily and autonomously, from flexibility to an ability to influence teammates and inspire subordinates.

\footnotetext{
${ }^{17}$ For a similar opinion, see Steedman et al. (1991) and Caroli (2001). Indirect evidence of the unfulfilled need for more general knowledge at the intermediate and bottom levels of the occupational structure is the underutilisation of graduates at the shopfloor level, see Mason (1996) and Mason and Finegold (1997).

${ }_{18}$ Among studies which consider the skill bias in services as well in manufacturing see Autor et al. (1998); Gera et al. (1999); Mairesse et al. (2001); Falk and Koebel (2003). However, only a few studies have specifically investigated the skill bias in service sectors (see, for instance, Kaiser, 2000 and Evangelista, 2000).
} 
Indeed, this suggestion concerning education policy may apply to both the micro and the macroeconomic level. For instance, in a recent paper analysing the skill bias in French manufacturing over the period 1984-1995, Maurin and Thesmar (2003) have found a clear tendency for jobs that can be programmed in advance to be replaced by ones that require constant adaptation to change. Once again, this makes the case for general rather than vocational/specific/technical education and training (see Nelson and Phelps, 1966) ${ }^{19}$.

Finally and still at the aggregate level, if organisational change (possibly combined with technological change) proves to be "knowledge biased" for all the levels of the workforce, the concept of a "learning society" warrants closer attention, and should shape the evolution of education policies. Thus, the building of a learning society should not be seen solely as a necessary response to the technical challenges raised by the "new economy" and the ICT revolution; it should also be viewed as an institutional context favouring the diffusion of general knowledge, social and communication skills, and "learn how to learn" capabilities (see Lundvall, 1992; Lundvall and Johnson, 1994; Lundvall et al., 2002).

\section{Conclusions}

The recent theoretical and empirical literature has focused on the coevolution of technological and organisational change within firms. One implication of these studies is that skill upgrading is no longer a consequence of technological change alone, but is also an effect of the overall reorganisation of the firm, which in turn may be linked to technological change.

\footnotetext{
${ }^{19}$ On this basis, Krueger and Kumar (2003a and 2003b) have put forward a theoretical macroeconomic model where they show that European education policies favouring specialized education may have worked well in the 1960s and 1970s when technologies were more stable and European countries were involved in catching-up, but they may have had a role in increasing the European growth gap relative to the US during the 1980s and 1990s, when new ICT technologies emerged at a very rapid pace.
} 
This paper has offered new evidence supporting the hypothesis of a superadditive effect of technological and organisational change on the skill composition of Italian manufacturing employment. In particular, it has shown a) that the alleged role of R\&D alone in determining skill bias is not confirmed by econometric estimations, b) that significant organisational changes made by a firm to its structure and functions are major factors affecting skill composition, and $c$ ) that interacting the $R \& D$ and the Organisation (ORG) variables yields higher and more significant coefficients, also in comparison with ORG in previous estimates. If such is the nature of the skill bias, a possible implication for education and training policies is that general knowledge - including non cognitive capabilities - should be fostered at the expenses of technical/specific knowledge. The correlated hypothesis of general rather than vocational education as one of the factors positively affecting both firm's performance and aggregate economic growth paves the way for further research. 


\section{References}

Acemoglu, D., 1998. Why do new technologies complement skills? Directed technical change and wage inequality, Quarterly Journal of Economics 113, 1055-1090.

Adams, J.D., 1999. The structure of firm R\&D, the factor intensity of production and skill bias, Review of Economics and Statistics 81, 499-510.

Aghion, P., Caroli, E., García-Peñalosa, C., 1999. Inequality and economic growth: the perspective of the new growth theories, Journal of Economic Literature 37, 1615-1660.

Aghion, P., Howitt, P., 2002. Wage inequality and the new economy, Oxford Review of Economic Policy 18, 306-323.

Aguirregabiria, V., Alonso-Borrego, C., 2001. Employment occupational structure, technological capital and reorganisation of production, Labour Economics 8, 43-73.

Aoki, M., 1986, Horizontal vs. vertical information structure of the firm, American Economic Review 76, 971-983.

Autor, D., Katz, L., Krueger, A., 1998. Computing inequality: have computers changed the labor market?, Quarterly Journal of Economics 113, 1169-1214.

Berle, A., Means, G., 1932. The Modern Corporation and Private Property. Macmillan, New York.

Berman, E., Bound, J., Griliches, Z., 1994. Changes in the demand for skilled labor within U.S. manufacturing industries: evidence from the Annual Survey of Manufacturing, Quarterly Journal of Economics 109, 367-397.

Betts, J., 1997. The skill bias of technological change in Canadian manufacturing industries, Review of Economics and Statistics 79, 46-50.

Black, S.E., Lynch, L.M., 2001. How to compete: the impact of workplace practices and information technology on productivity, Review of Economics and Statistics 83, 434-445.

Bolton, P., Dewatripont, M., 1994. The firm as a communication network, Quarterly Journal of Economics 109, 809-839.

Bresnahan, T.F., 1999. Computerisation and wage dispersion: an analytical reinterpretation, Economic Journal 109, 390-415.

Bresnahan, T.F., Brynjolfsson, E., Hitt, L.M., 2002. Information technology, workplace organization and the demand for skilled labor: firm-level evidence, Quarterly Journal of Economics 117, 339-376.

Bresnahan, T.F., Trajtenberg, M., 1995. General purpose technologies: "engine of growth"?, Journal of Econometrics 65, 83-108.

Brynjolfsson, E., Mendelson, H., 1993. Information systems and the organization of modern enterprise, Journal of Organizational Computing 3, 245-255.

Brynjolfsson, E., Hitt, L.M., 1998. Information technology and organizational design: evidence from micro data, mimeo. MIT Press, Cambridge (Mass.).

Brynjolfsson, E., Hitt, L.M., 2000. Beyond computation: information technology, organizational transformation and business performance, Journal of Economic Perspectives 14, 23-48.

Brynjolfsson, E., Renshaw, A., Alstyne, M.V., 1997. The matrix of change, Sloan Management Review 38, 22-40.

Burkart, M., Panunzi, F., Shleifer, A., 2002. Family firms, NBER Working Paper Series 8776.

Caroli, E., 2001. New technologies, organizational change and the skill bias: what do we know?, in: P.Petit and L.Soete (Eds.), Technology and the Future of European Employment, Elgar, Cheltenham, 259-292. 
Caroli, E., Greenan, N., Guellec, G., 2001. Organizational change and skill accumulation, Industrial and Corporate Change 10, 479-504.

Caroli, E., Van Reenen, J., 2001. Skill biased organizational change? Evidence from a panel of British and French establishments, Quarterly Journal of Economics 116, 1449-1492.

Chandler, A., 1962. Strategy and Structure. MIT Press, Cambridge (Mass.).

Christensen, L.R., Jorgenson, D.W., Lau, L.J., 1971. Conjugate duality and the transcendental logarithmic production function, Econometrica 39, 255-256.

Christensen, L.R., Jorgenson, D.W., Lau, L.J., 1973. Transcendental logarithmic production frontiers, Review of Economics and Statistics 55, 28-45.

Colombo, M., Delmastro M. (2002), The determinants of organizational change and structural inertia: Technological and organizational factors, Journal of Economics \& Management Strategy, 11, 595-635

Doms, M., Dunne, T., Troske, K., 1997. Workers, wages and technology, Quarterly Journal of Economics 112, 253-290.

Dosi, G., 1988. Sources, procedures and microeconomic effects of innovation, Journal of Economic Literature 26, 1120-1171.

Dunne, M., Haltiwanger, J., Troske, K., 1996. Technology and jobs: secular changes and cyclical dynamics, NBER Working Paper Series 5656.

Evangelista, R., 2000. Innovation and employment in services: results from the Italian Innovation Survey, in: M.Vivarelli and M.Pianta (Eds.), The Employment Impact of Innovation: Evidence and Policy. Routledge, London, 121-148.

Falk, M., 1999. Technological innovations and the expected demand for skilled labour at the firm level, ZEW Discussion Paper 99-59.

Falk, M., Koebel, B.M., 2003. The impact of office machinery and computer capital on the demand for heterogeneous labour, IZA Discussion Paper 873.

Freeman, C., Louçã, F., 2001. As Time Goes by: From the Industrial Revolutions to the Information Revolution. Oxford University Press, Oxford.

Freeman, C., Soete, L., 1994. Work for All or Mass Unemployment? Computerised Technical Change into the Twenty-first Century. Pinter, London and New York.

Fuà, G., 1988. Small-scale industry in rural areas: the Italian experience, in: K.J.Arrow (Ed.), The Balance between Industry and Agriculture in Economic Development. Macmillan for the International Economic Association, London, 259-279.

Gera, S., Gu, W., Lin, Z., 1999. Technology and the demand for skills: an industry level analysis, Working Paper 28, Industry Canada Research Publications Program.

Gibson, J., 2002. Have computers changed the New Zealand wage structure? Evidence from data on training, paper presented at the $10^{\text {th }}$ Labour, Employment and Work Conference, Victoria University of Wellington, 21-22 November.

Goldin, C., Katz, L., 1998. The origins of technology-skill complementarity, Quarterly Journal of Economics 113, 693-732.

Goux, D., Maurin, E., 2000. The Decline in demand for unskilled labor: an empirical analysis and its application to France, The Review of Economics and Statistics 82, 596-607.

Greenan, N., 1996a. Innovation technologique, changements organisationnels et evolution des compétences, Economie et Statistique 298, 15-34.

Greenan, N., 1996b. Progrès technique et changements organisationnels: leur impact sur l'emploi et les qualifications, Economie et Statistique 298, 35-44. 
Greenan, N., 2003. Organisational change, technology, employment and skills: an empirical study of French manufacturing, Cambridge Journal of Economics 27, 287-316.

Greenan, N., Guellec, D., 1994. Coordination within the firm and endogenous growth, Industrial and Corporate Change 3, 173-197.

Greenan, N., Guellec, D., 1998. Firm organization, technology and performance: an empirical study, Economics of Innovation and New Technology 6, 313-347.

Greenan, N., Mairesse, J., 1999. Organizational change in French manufacturing: what do we learn from firm representatives and from their employees?, NBER Working Paper 7285.

Greiner, A., Rubart, J., Semmler, W., 2001. Economic growth, skill-biased technical change and wage inequality: a model and estimation for the US and Europe, mimeo, University of Bielefeld, Department of Economics.

Haskel, J.E., Heden, Y., 1999. Computers and the demand for skilled labour: industry and establishment-level evidence for the UK, Economic Journal 109, C68-C79.

Haskel, J.E., Slaughter, M.J., 2002. Does the sector bias of skill-biased technical change explain changing skill premia?, European Economic Review 46, 1757-1783.

Hitt, L., Brynjolfsson, E., 1997. Information technology and internal firm organization: an exploratory analysis, Journal of Management Information Systems 14, 81-101.

Hitt, L., Brynjolfsson, E., 2002. Information technology, organizational transformation, and business performance, in: N.Greenan, Y.L'Horty and J.Mairesse (Eds.), Productivity, Inequality, and the Digital Economy: A Transatlantic Perspective. MIT Press, Cambridge (Mass.), 55-91.

Ichniowski, C., Shaw, K., 2003. Beyond incentive pay: insiders' estimates of the value of complementary Human Resources Management Practices, Journal of Economic Perspectives 17, 155-180.

Ichniowski, C., Shaw, K., Prenushi, G., 1997. The effects of Human Resource Management practices on productivity: a study of steel finishing lines, American Economic Review 87, 291-313.

Kaiser, U., 2000. New technologies and the demand for heterogeneous labor: firm-level evidence for the German business-related service sector, Economics of Innovation and New Technology 9, 465-486.

Kleinknecht, A., 2000. Indicators of manufacturing and service innovation: their strengths and weaknesses, in: J.S.Metcalfe, and I.Miles (Eds.), Innovation Systems in the Service Economy: Measurement and Case Study Analysis. Kluwer, Boston, 169-186.

Kmenta, J., 1967. On estimation of the CES production function, International Economic Review 8, 180-189.

Krueger, A., 1993. How computers have changed the wage structure: evidence from micro data 1984-1989, Quarterly Journal of Economics 108, 33-60.

Krueger, D., Kumar, K.B., 2003a. Skill specific rather than general education: a reason for USEurope growth differences?, NBER Working Paper 9408.

Krueger, D., Kumar, K.B., 2003b. US-Europe differences in technology-driven growth: quantifying the role of education, NBER Working Paper 10001.

Lindbeck, A., Snower, D., 1996. Reorganization of firms and labor-market inequality, America Economic Review, AEA Papers and Proceedings 86, 315-321.

Lundvall, D.A. (Ed.), 1992. National System of Innovation. Towards a Theory of Innovation and Interactive Learning. Pinter, London.

Lundvall, D.A., Johnson, B., 1994. The learning economy, Journal of Industry Studies 1, 23-42. 
Lundvall, D.A., Johnson, B., Andersen, E.S., Dalum, B., 2002. National systems of production, innovation and competence building, Research Policy 31, 213-231.

Machin, S., 1996. Changes in the relative demand for skills in the UK labor market, in: A.,Booth and D.,Snower (Eds.) Acquiring Skills: Market Failures, Their Symptoms and Policy Responses. Cambridge University Press, Cambridge, 129-146.

Machin, S., Ryan, A., Van Reenen, J., 1996. Technology and changes in skill structure: evidence from an international panel of industries, CEPR Discussion Paper 297.

Machin, S., Van Reenen, J., 1998. Technology and changes in the skill structure: evidence from seven OECD countries, Quarterly Journal of Economics 113, 1215-1244.

Mairesse, J., Greenan, N., Topiol-Bensaïd, A., 2001. Information technology and research and development impacts on productivity and skills: a comparison on French firm level data, NBER Working Paper 8075.

Manasse, P., Stanca, L., Turrini, A., 2003. Wage premia and skill upgrading in Italy: why didn't the hound bark?, Labour Economics, forthcoming.

Mason, G., 1996. Graduate utilisation in British industry: the initial impact of mass higher education, National Institute Economic Review 156, 93-103.

Mason, G., Finegold, D., 1997. Productivity, machinery and skills in the United States and Western Europe, National Institute Economic Review 162, 85-98.

Maurin, E., Thesmar, D., 2003. Changes in the functional structure of firms and the demand for skill, CEPR Discussion Paper 3831.

Michel, L., Bernstein, J., 1996. Technology and the wage structure: has technology impact accelerated since the 1970s?, Working Paper of the Economic Policy Institute.

Milgrom, P., Roberts, J., 1990. The economics of modern manufacturing: technology, strategy, and organization, American Economic Review 80, 511-528.

Milgrom, P., Roberts, J., 1995. Complementarities and firms: strategy, structure and organisational change in manufacturing, Journal of Accounting and Economics 19, 179208.

Nelson, R.R., Phelps, E., 1966. Investments in humans, technological diffusion, and economic growth, American Economic Review 56, 69-75.

Nelson, R., Winter, S.G., 1982. An Evolutionary Theory of Economic Change. Harvard University Press, Cambridge.

Nickell, S., Bell, B., 1995. The collapse in demand for the unskilled and unemployment across the OECD, Oxford Review of Economic Policy 11, 40-62.

OECD, 1996. The evolution of skills in OECD countries and the role of technology, STI Working Paper 1996/8.

OECD, 1998. OECD data on skills: employment by industry and occupation, STI Working Paper $1998 / 4$.

OECD, 1999. Economic opening and the demand for skills in developing countries - A review of theory and evidence, Technical Paper 149.

Osterman, P., 1994. How common is workplace transformation and who adopts it?, Industrial and Labour Relations Review 47, 173-188.

Pavitt, K., Robson, M., Townsend, J., 1989. Technological accumulation, diversification and organization in UK companies, 1945-83, Management Science 35, 81-99.

Petit, P., Soete, L., 2001. Technical change and employment growth in services: analytical and policy challenges, in P.Petit and L.Soete (Eds.), Technology and the Future of European Employment. Elgar, Cheltenham, 166-203. 
Pianta, M., 2003. Innovation and employment, in: I.Fagerberg, D.Mowery and R.R.Nelson (Eds.), Handbook of Innovation. Oxford University Press, Oxford, forthcoming.

Piergiovanni, R., Santarelli, E., 1996. Analyzing literature-based innovation output indicators: the Italian experience, Research Policy 25, 689-711.

Piergiovanni, R., Santarelli, E., Vivarelli, M., 1997. From which source do small firms derive their innovative inputs? Some evidence from Italian manufacturing, Review of Industrial Organization 12, 243-258.

Piva, M., Vivarelli, M., 2002. Skill-bias: comparative evidence and econometric test, International Review of Applied Economics 16, 347-357.

Piva, M., Vivarelli, M., 2004. The determinants of the skill bias in Italy: R\&D, organisation or globalisation?, Economics of Innovation and New Technology 13, forthcoming.

Radner, R., 1993. The organization of decentralized information processing, Econometrica 61, 1109-1146.

Siegel, D.S., 1998. The impact of technological change on employment: evidence from a firmlevel survey of Long Island manufacturers, Economics of Innovation and New Technology 5, 227-246.

Siegel, D.S., Waldman, D., Youngdahl, D.W., 1997. The adoption of advanced manufacturing technologies: Human Resource Management implications, IEEE Transactions on Engineering Management 44, 288-298.

Slaughter, M., 2000. Production transfers within multinational enterprises and American wages, Journal of International Economics 50, 449-472.

Steedman, H., Mason, G., Wagner, K., 1991. Intermediate skills in the workplace: deployment, standards and supply in Britain, France and Germany, National Institute Economic Review 136, 60-76.

Thesmar, D., Thoenig, M., 2000. Creative destruction and firm organization choice: a new look into the growth inequality relationship, Quarterly Journal of Economics 115, 1201-1237.

Von Tunzelmann, N., Anderson, E., 1998. Technology, trade and wage inequalities in the late nineteenth century, in: M.Berg and K.Bruland (Eds.), Technological Revolutions in Europe: Historical Perspectives. Elgar, Cheltenham, 241-272.

Wood, A., 1994. North-South Trade, Employment, and Inequality: Changing Fortunes in a Skilldriven World. Clarendon Press: Oxford.

Wood, A., 1995. How trade hurts unskilled workers, Journal of Economic Perspectives 9, 57-80.

Zellner, A., 1962. An efficient method of estimating seemingly unrelated regression and tests for aggregation bias, Journal of the American Statistical Association 57, 348-368. 
Figure 1. Shares (percentage values) of white-collar workers in manufacturing employment in the G-7 countries.

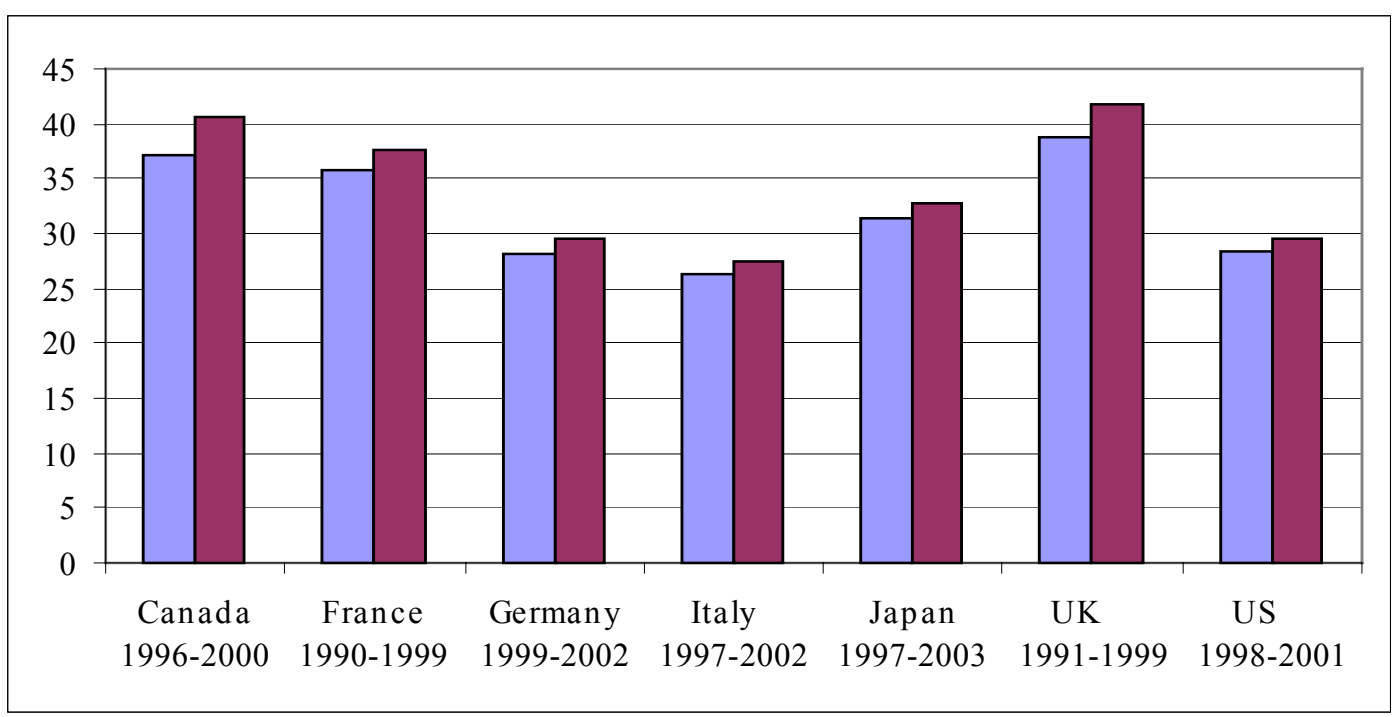

\section{Sources}

Canada: Based on Population Census, Statistics Canada; France: Based on Recensements de la Population, INSEE; Germany: Based on Employment Register, IAB Germany; Italy: Based on Sistema Informativo Excelsior, Unioncamere; Japan: Based on Labour Force Survey and Population Census (data include also the construction sector; 2003 data are relative to the month of June), Statistics Bureau; United Kingdom: Based on Labour Force Survey, Office for National Statistics; United States: Based on Population Census, US Bureau of Labor Statistics. 
Table 1. SUR estimates of changes in the demand for WC and BC between 1997-91

\begin{tabular}{|c|c|c|c|c|c|c|}
\hline & $\begin{array}{c}(1) \\
\text { dlWC }\end{array}$ & $\begin{array}{r}(2) \\
\text { dlBC }\end{array}$ & $\begin{array}{c}(3) \\
\text { dlWC }\end{array}$ & $\begin{array}{c}(4) \\
\text { dlBC }\end{array}$ & $\begin{array}{c}(5) \\
\text { dlWC }\end{array}$ & $\begin{array}{c}(6) \\
\text { dlBC }\end{array}$ \\
\hline Constant & $\begin{array}{l}-0.17 * * * \\
(2.72)\end{array}$ & $\begin{array}{l}-0.14 * * \\
(2.08)\end{array}$ & $\begin{array}{l}0.15^{* *} \\
(2.01)\end{array}$ & $\begin{array}{l}0.02 \\
(0.26)\end{array}$ & $\begin{array}{l}0.16^{* *} \\
(2.14)\end{array}$ & $\begin{array}{c}0.003 \\
(0.05)\end{array}$ \\
\hline Sales & $\begin{array}{l}0.32 * * * \\
(5.77)\end{array}$ & $\begin{array}{l}0.38^{* * * *} \\
(6.33)\end{array}$ & $\begin{array}{l}0.31 * * * \\
(5.64)\end{array}$ & $\begin{array}{l}0.39 * * * \\
(6.53)\end{array}$ & $\begin{array}{l}0.31^{* * * *} \\
(5.49)\end{array}$ & $\begin{array}{l}0.40^{* * *} \\
(6.60)\end{array}$ \\
\hline Capital & $\begin{array}{l}0.04 \\
(1.15)\end{array}$ & $\begin{array}{l}0.09 * * \\
(2.50)\end{array}$ & $\begin{array}{l}0.04 \\
(1.06)\end{array}$ & $\begin{array}{l}0.10 * * * \\
(2.63)\end{array}$ & $\begin{array}{l}0.04 \\
(1.09)\end{array}$ & $\begin{array}{l}0.10^{* * *} \\
(2.59)\end{array}$ \\
\hline Wages & $\begin{array}{l}-0.60 * * * \\
(6.99)\end{array}$ & $\begin{array}{l}-0.01 \\
(0.06)\end{array}$ & $\begin{array}{l}-0.59 * * * \\
(6.95)\end{array}$ & $\begin{array}{l}-0.01 \\
(0.16)\end{array}$ & $\begin{array}{l}-0.59^{* * *} \\
(6.91)\end{array}$ & $\begin{array}{l}-0.02 \\
(0.17)\end{array}$ \\
\hline $\mathrm{R} \& \mathrm{D}$ & $\begin{array}{l}0.01 \\
(0.28)\end{array}$ & $\begin{array}{l}-0.02 \\
(0.43)\end{array}$ & & & & \\
\hline ORG & & & $\begin{array}{l}0.06 \\
(1.49)\end{array}$ & $\begin{array}{l}-0.08 \\
(1.81)^{*}\end{array}$ & & \\
\hline ORG*R\&D & & & & & $\begin{array}{l}0.08^{*} \\
(1.69)\end{array}$ & $\begin{array}{l}-0.11 * * \\
(2.00)\end{array}$ \\
\hline $\begin{array}{l}\text { Fixed effects: } \\
\text { TB }\end{array}$ & $5.56^{*}$ & 1.20 & $5.87 *$ & 1.11 & $5.76^{*}$ & 1.17 \\
\hline Size & $25.45^{* *}$ & $14.73 * * *$ & $26.12 * * *$ & $12.47 * *$ & $26.93 * * *$ & * $12.86^{* *}$ \\
\hline $\mathrm{R}^{2}$ & 0.23 & 0.19 & 0.24 & 0.19 & 0.24 & 0.19 \\
\hline Observations & 400 & 400 & 400 & 400 & 400 & 400 \\
\hline
\end{tabular}

Notes:

- t-statistics in brackets: $*$ significant at $10 \%$; ** significant at $5 \%, * * *$ significant at $1 \%$.

- R\&D and ORG refer to the three-year period 1989-91; WC, BC, sales, capital and wages are all expressed as a difference of the logarithm (1997-91).

- With reference to the fixed effects $(\mathrm{TB}=$ takeovers and breakups; Size $=$ five firm's size classes) the result of a Wald test is given, under the null hypothesis of zero value of the relevant dummies.

- All the three models reveal to be superior to OLS estimates, according to the relative BreuschPagan's tests: $\chi^{2}(1)=74.143^{* * *}, \chi^{2}(1)=73.147^{* * *}, \chi^{2}(1)=72.784^{* * *}$. 